DOI 10.22460/infinity.v6i2.p111-120

\title{
EFFECT OF LEARNING WITH ABDUCTIVE-DEDUCTIVE STRATEGY TOWARDS THE ACHIEVEMENT OF REASONING ABILITY OF HIGH SCHOOL STUDENTS
}

\author{
Ali Shodikin \\ Universitas Islam Darul Ulum, Jl. Airlangga No. 3 Sukodadi Lamongan, Indonesia \\ aliandr4@gmail.com
}

Received: February 08, 2017 ; Accepted: May 12, 2017

\begin{abstract}
The purpose of this study was to investigate the effect of learning with abductive-deductive strategy towards the achievement of mathematical reasoning abilities of high school students. Research carried out an experimental pretest-posttest design and the control group was not randomized in class XI student at one high school in Pati, Central Java, Indonesia. Data analysis was conducted quantitative research based on early mathematical ability categories (KAM) and overall. The results showed that the achievement of mathematical reasoning abilities that students acquire learning abductive-deductive strategy better than students who received the expository learning. In more detail of KAM categories, only middle category that show achievement of mathematical reasoning abilities better. While in upper and under categories have the same reasoning abilities achievements. This research is expected teachers can encourage students to do abduction and deduction in the learning achievement of students' mathematical reasoning abilities.
\end{abstract}

Keywords: Abductive-Deductive Strategy, Achievement, Reasoning.

\begin{abstract}
Abstrak
Tujuan penelitian ini adalah menginvestigasi pengaruh pembelajaran dengan strategi abduktif-deduktif terhadap pencapaian kemampuan penalaran matematis siswa SMA. Penelitian yang dilakukan merupakan eksperimental dengan desain pretes-postes dan kelompok kontrol tidak acak (nonrandomized control group, pretest-posttest design) pada siswa kelas XI di salah satu SMA di Kabupaten Pati, Jawa Tengah, Indonesia. Analisis data penelitian dilakukan secara kuantitatif berdasarkan kategori kemampuan awal matematis (KAM) maupun keseluruhan. Hasil penelitian menunjukkan bahwa pencapaian kemampuan penalaran matematis siswa yang mendapatkan pembelajaran dengan strategi abduktif-deduktif lebih baik daripada siswa yang mendapat pembelajaran ekspositori. Secara lebih rinci dari kategori KAM, hanya pada kategori tengah yang menunjukkan pencapaian kemampuan penalaran matematis yang lebih baik. Sedangkan pada kategori atas dan bawah memiliki pencapaian kemampuan penalaran yang sama. Dari penelitian ini diharapkan guru dapat mendorong siswa untuk melakukan abduksi dan deduksi dalam pembelajaran dalam pencapaian kemampuan penalaran matematis siswa.
\end{abstract}

Kata Kunci: Strategi Abduktif-Deduktif, Pencapaian, Penalaran.

How to Cite: Shodikin, A. (2017). Effect of Learning with Abductive-Deductive Strategy Towards the Achievement of Reasoning Ability of High School Students. Infinity, 6 (2), 111120. doi:10.22460/infinity.v6i2.p111-120 


\section{INTRODUCTION}

Mathematical reasoning ability is the main characteristic that can't be separated from the activities of studying and developing or solving mathematical problems. Reasoning in mathematics plays a critical role in developing mathematical understandings. (Bragg, Loong, Widjaja, Vale, \& Herbert, 2015). In fact, the implementation of learning that emphasizes the existence of reasoning is very recommended (NCTM, 2000). There were strong positive relationships between the students' spatial reasoning and mathematics performance (Lowrie, Logan \& Ramful, 2016). However, many studies show that the reasoning ability of students is still low (Nataliasari, 2014). Their thinking of algebraic reasoning required only procedural knowledge and did not include generalisation or functional thinking (Glassmeyer \& Edwards, 2016). Though reasoning ability is needed in the mastering and solving of mathematical problems. But this reasoning ability is often overlooked in learning (Nizar, 2007). Therefore, in learning mathematics mathematical reasoning ability need attention given to be able to solve a math problem required students' reasoning abilities. Report the results of other studies, showed similar findings. Reasoning ability which a part of high order mathematical thinking abilities (Sumarmo, 2013). Study reports Mullis, Martin, Ruddock, O’Sollivan \& Preuschoff (2009) show that learning mathematics is generally not focused on developing high order mathematical thinking abilities. Student more dominant solve problems from the textbook and get less non-routine problems that can train this high order mathematical thinking abilities. Thus the need for efforts to develop mathematics learning oriented to the development of high order thinking abilities.

Based on a preliminary analysis of reasoning ability is necessary to develop a learning that can improve the understanding of essential concepts. As a general framework in solve a problem in mathematics is the ability to identify the given facts (data) and formulate what is asked in the problem (final target). In determining the final target is based on data provided, it is necessary to elaborate the ability to apply the essential concepts that are relevant with the given data to obtain intermediate target before finding the answer to the final target. Not a few problems in mathematics can be more easily solved by adding a condition (intermediate target) that is based on a concept relevant essential to arrive at the final target in question.

General framework as described above has been developed at the research Shodikin (2016) in a learning with abductive-deductive strategy. Abductive is a mathematical thinking skills (reasoning) that can't fully answer the problem but the process of offering a reason as the basis for a specific action (Aliseda, 2007). This general framework was originally developed to develop the proving ability the beginner student learning of proof. The results showed that student who learn with abductive-deductive strategy have the proving ability better than students who learn with conventional learning. Possible application of this strategy has been reviewed by Sun, Finnie \& Weber (2005) for the problem of reasoning and problem solving ability. The possibility of applying this framework to the wide range problems (mathematical literacy) for students in secondary schools has also been studied theoretically (Shodikin, 2013).

Based on the notion of learning with abductive-deductive strategy, in this study developed learning syntax abductive-deductive strategy more operational as shown in Figure 1. 


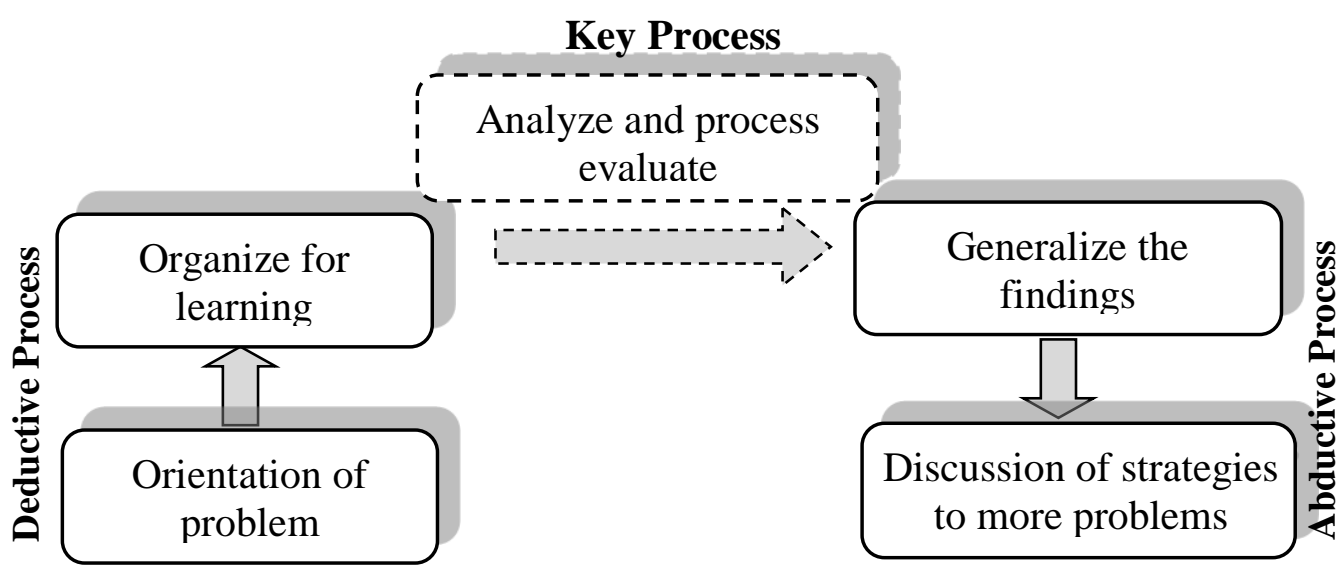

Figure 1. Schematic of Learning with Abductive-Deductive Strategy

Stages of learning with abductive-deductive strategy above in more detail is shown in Table 1 (Shodikin, 2016).

Table 1. Syntax of Learning with Abductive-Deductive Strategy

\section{Phase} Teacher Behavior

\begin{tabular}{|c|c|c|}
\hline Phase 1 & Orientation of problem & $\begin{array}{l}\text { - Teacher discusses the problem of learning objectives } \\
\text { - Teachers describe various important logistics needs } \\
\text { - Teachers motivate students to be directly involved in } \\
\text { learning activities } \\
\text { - Teachers provide apperception }\end{array}$ \\
\hline
\end{tabular}

Phase 2 Organize for learning - Teachers help students to define and organize the tasks of learning and information related to the problem

\begin{tabular}{|c|c|c|}
\hline Phase 3 & $\begin{array}{l}\text { Analyze and process } \\
\text { evaluate }\end{array}$ & $\begin{array}{l}\text { - Analyze and evaluate the teacher directs students to } \\
\text { find their own solutions from information already } \\
\text { possessed by students } \\
\text { - Teachers encourage students to do transactive } \\
\text { reasoning as to criticize, explain, clarify, justify and } \\
\text { elaborate a proposed idea, either initiated by students } \\
\text { and teachers } \\
\text { - Teachers assist students in planning and preparing } \\
\text { materials for presentations and discussion } \\
\text { - Teachers help students to reflect on the investigation } \\
\text { process and other processes used in solving problems }\end{array}$ \\
\hline Phase 4 & Generalize the findings & - Teachers help generalize the findings obtained \\
\hline Phase 5 & $\begin{array}{l}\text { Discussion of strategies } \\
\text { to more problems }\end{array}$ & $\begin{array}{l}\text { - Teachers assist students in finding strategies to the } \\
\text { problems are much more } \\
\text { - Teachers provide training and evaluation }\end{array}$ \\
\hline
\end{tabular}


To be involved in transactive discussion, early mathematics ability (KAM) student plays a very important, where an idea that appears to develop gradually so as to build a comprehensive mathematical concept of information obtained. The KAM students are categorized into three categories: upper, middle and under. This grouping is used to see if there is mutual effect between the learning is done with early mathematics ability of the students' reasoning abilities. Besides that, it can be obtained more detail the effect of learning in each category of early mathematical ability.

Based on the background and formulation of the problem described above, this study aims to investigate the influence learning abductive-deductive strategy towards the achievement of high school students' mathematical reasoning abilities.

\section{METHOD}

The method applied in this study is experimental with pretest-posttest design and the control group was not randomized. With this design, subjects initially performed pretest, and then treated with a form of learning abductive-deductive strategy and then performed post-test to measure students' mathematical reasoning abilities in polynomial of matter. This design is chosen according to the purpose of research to show the effect of the application of learning with abductive-deductive strategy towards the achievement of students' mathematical reasoning ability. In the chart of design used are presented in Figure 2.

\begin{tabular}{|c|c|c|c|}
\hline $\begin{array}{l}\text { Experimental } \\
\text { Class }\end{array}$ & $\begin{array}{c}\mathbf{O} \\
\text { Pretest }\end{array}$ & $\begin{array}{c}\mathbf{X}_{\mathbf{1}} \\
\text { Treatment } \\
\text { Abductive-Deductive } \\
\text { Strategy }\end{array}$ & $\begin{array}{c}\mathbf{O} \\
\text { Posttest }\end{array}$ \\
\hline $\begin{array}{c}\text { Control } \\
\text { Class }\end{array}$ & $\begin{array}{c}\mathbf{O} \\
\text { Pretest }\end{array}$ & $\begin{array}{c}\mathbf{X}_{\mathbf{2}} \\
\text { Treatment } \\
\text { Expository }\end{array}$ & $\begin{array}{c}\mathbf{O} \\
\text { Posttest }\end{array}$ \\
\hline
\end{tabular}

Figure 2. Design Research

The study was conducted at one high school in Pati, Central Java, Indonesia. The samples have been two classes that have the same initial capabilities of the eight classes by random sampling, each totaling 34 students. Grouping students by category early mathematical ability (KAM) is obtained from the average value of two daily tests, mid semester test and semester test.

\section{RESULTS AND DISCUSSION}

\section{Results}

The selection of the class which is used as a sample study in addition seen early mathematical abilities seen from the initial reasoning abilities of students obtained from the pretest scores, both overall and by category KAM. It has been shown that the students is learning with abductive-deductive strategies and students learning expository no difference in early mathematical ability of reasoning, both in terms of overall and by category KAM (upper, middle, under). 
Achievement of mathematical reasoning ability obtained through posttest scores. Based on calculations, the achievement of mathematical reasoning abilities obtained an average value based on class research (experimental and control) and KAM (upper, middle, under) are presented in the following bar chart.

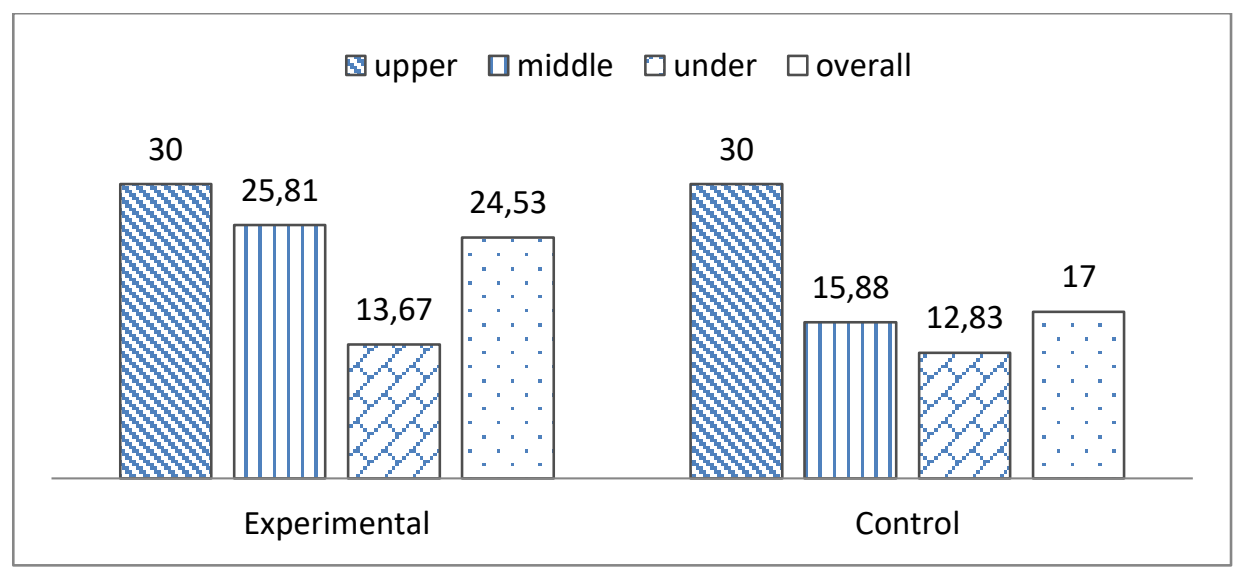

Figure 3. Achievement Score Bar Chart Reasoning Ability

Figure 3 show that the students who received learning with abductive-deductive strategy (experimental class) shows the overall average achievement of mathematical reasoning abilities greater than students who received the expository learning(controlclass). Judging from KAM category is upper the level students' KAM, greater the average achievement of mathematical reasoning ability.

To find out the reasoning abilities of learning achievement of which one is better,do mean difference test. Before the test the average difference, the normality test and homogeneity tests. Mean difference test used the t-test for normally distributed data and homogeneous. While the pair is not normally distributed data were analyzed using Mann-Whitney U nonparametric test. Results mean differences test are presented in Table 2.

Table 2. Test Results Mean Differences Pos-test Score Mathematical Reasoning Ability

\begin{tabular}{ccccccr}
\hline KAM & $\begin{array}{c}\text { Comparison } \\
\text { of average } \\
(\mathbf{E}: \mathbf{K})\end{array}$ & $\mathbf{T}$ & $\begin{array}{c}\text { Mann- } \\
\text { Whitney } \mathbf{U}\end{array}$ & $\begin{array}{c}\text { Sig. } \\
(\mathbf{2} \text { tailed })\end{array}$ & $\begin{array}{c}\text { Sig. } \\
(\mathbf{1} \text { tailed })\end{array}$ & Ho \\
\hline Upper & $30.00: 30.00$ & 0.000 & - & 1.000 & 0.500 & Accept \\
Middle & $25.81: 15.88$ & - & 130.5 & 0.006 & 0.003 & Reject \\
Under & $13.67: 12.83$ & 0.166 & - & 0.871 & 0.435 & Accept \\
\hline Overall & $24.53: 17.00$ & - & 304.5 & 0.001 & 0.000 & Reject \\
\hline
\end{tabular}

Ho: The average student achievement reasoning abilities experimental class lower or equal to the control class in terms of KAM (upper, middle, under) as well as overall.

Table 2 shows that the mathematical reasoning ability students acquire learning with abductive-deductive strategy (experimental class) better than students who acquire expository 
learning (control class). Seen more detail from the KAM category, only in the middle category, achievement of students' mathematical reasoning ability that acquire learning with abductive-deductive strategy better than students who acquire expository learning. But in the upper and under category of KAM, the achievement of mathematical reasoning ability students acquire learning abductive-deductive strategy (experimental class) is lower or equal to the students who acquire learning expository (control class). After seeing the average achievement, the upper and under category gained an average the experimental class greater than average control class, so concluded the achievement of mathematical reasoning abilities that students acquire learning with abductive-deductive strategy (experimental class) equals students who acquire the expository learning (control class).

\section{Discussion}

Specifically indicator mathematical reasoning ability as measured focused on three skills namely (1) make logical conclusions; (2) estimate answers and solution processes; and (3) use patterns and relationships to analyze mathematical situations.

It has been shown that the students who acquire learning with abductive-deductive strategy and expository learning no difference in mathematical ability early of reasoning, both in terms of overall and by category KAM (upper, middle,under). This is normal, because both classes have not been subjected to different learning.

Achievement of mathematical reasoning ability students who acquire learning with abductivedeductive strategy is better than students acquire expository learning. These results are consistent with the hypothesis proposed previously and showed that indeed the phases of learning with abductive-deductive strategy to support and facilitate the improvement of students' reasoning abilities. The results of this study as well as the findings of the study other researchers which states that students who acquire learning with the mathematical process thinking has the reasoning abilities better than conventional learning, specifically for metacognitive (Noto, 2015) and reflective (Rohana, 2015). Although the research conducted at the different levels of students and inductive approach, but its similarity to learning with abductive-deductive strategy is equally a kind of learning that emphasizes the mathematical process thinking.

Average achievement scores (post-test) on the reasoning abilities of students acquire learning with abductive-deductive 24.53 of the ideal 40 score. From this data it can be concluded that the reasoning ability in students who acquire learning with abductive-deductive still less than optimal. The reason for this is related to adjustments in thought relatively difficult students. In fact, think hard into the main capital in constructing knowledge in view of constructivism based learning (Ormrod, 2008). Another reason is a test that is used in this study was relatively difficult. It is recognized by some of the current students do interviews, that the test items in this study is more difficult than the usual questions given by the teacher in the learning prior to the study. Recognition of students is in line with the test results that the questions used most difficult category. Whatever the reason is related to the achievement of the results are still far from optimal, it is of the low mathematical reasoning abilityhigh school studentsbased on this sample.

Descriptions make it clear that high order mathematical thinking ability (reasoning) is not an easy job. However, it is undeniable that the students who acquire learning with abductivedeductive strategy is able to demonstrate better achievement than students who obtain 
expository learning. This indicates that if the learning abductive-deductive strategy consistently applied it is possible to increase students' reasoning abilities optimally.

Reviewed in more detail by category KAM, only in the middle category that shows achievement of mathematical reasoning ability students acquire learning with abductivedeductive strategy better than students who acquire the expository learning. While the upper and under category achievement same ability. This suggests that learning with abductivedeductive strategy has been facilitated by both students with middle categories so as to improve mathematical reasoningability. While the student with upper categories, similarity results obtained in improving the ability of reasoning is possible for the students have been great motivation and ability to accept the learning that have been good too, so despite the lack of supporting learning though still able to obtain good results. Not much better reasoning ability enhancement students acquire learning with abductive-deductive strategy compared with expository learning does not mean that students do not improve ornot facilitated above, but with both of these learning both increased and facilitated. Similarly, the students with under categories, similarity results obtained in improvingreasoning ability in learning with abductive-deductive strategy and expository learning because the students with under categoryhave motivation and ability to accept the lesson less, so that although the learning support though still obtain less results. Based on that, in general learning with abductivedeductive strategy has been able to facilitate the achievement of better reasoning ability.

The following description seems to reinforce reasons the learning with abductive-deductive strategy has been able to facilitate the achievement of mathematical reasoning ability students better than the students who received learning expository. The following reasons are described by indicators measured reasoning ability.

Indicators (1) make logical conclusions. This indicator, in learning with abductive-deductive strategy facilitated the phase generalize the findings obtained. Learning activities that encourage students to generalize the findings obtained from the problems or the data obtained,was to familiarize and understand students to be able to make conclusions from a logically statement. This is in accordance with the opinion of Vygotsky (Jones \& Thornton, 1993), which is the process of improving the understanding and reasoning on students occurred as a result of learning. While the ability to generalize the findings needed reasoning abilities. In other words, the phase generalize the findings obtained in learning with abductive-deductive strategy has been able to facilitate the indicators make logical conclusions. If compared to expository learning, as experienced students the opportunity to learning with abductive-deductive strategy tends to be less. This is because the characteristics of expository learning that make it so.

Indicators (2) estimate answers and solutionsprocess in the learning with abductive-deductive strategy greatly facilitated in analyze and process evaluate phase. Stages of this phase, the teacher directs students to find their own solutions of the information that has been owned by the student. Teachers encourage students to do transactive reasoning as to criticize, explain, clarify, justify and elaborate a proposed idea, either initiated by students and teachers. Teachers assist students in planning and preparing materials for presentations and discussions. Teachers help students to reflect on the investigation process and other processes used in solving the problem of habituation to give students the ability to estimate answers and solution processes. Compared with expository in every phase of learning where the teacher presents the material in a way giving a lecture or reading material that students were prepared from a textbook or instructional materials are less certain to develop the ability to estimate 
answers and solution processes. This is supported by learning theories expressed by Peaget, where knowledge is not passively received. Mathematical knowledge is constructed by the children themselves should not be given in the form of so. It should students become active seekers and processors of information, not a passive recipient (Davis \& Murrell, 1994). In other words, students are given the opportunity to learn independently and connect the concepts that have been previously owned, and become involved in meaningful learning. Opportunity to explain the idea also be one of the factors supporting the increase in students' reasoning ability (Baig \& Halai, 2006). Students are involved in assessment for learning and of learning (Taylor \& Parsons, 2011). This is the value given to learning with abductivedeductive strategy compared with expository learning.

Indicators (3) use patterns and relationships to analyze mathematical situations in learning with abductive-deductive strategy facilitated in discussion of strategies to more problems phase. Activities of the students in finding strategies to the problems that require more students to see patterns and relationships between a problem with another problem. Students will construct a new mathematical knowledge through reflection on actions undertaken both physically and mentally. They made observations to find patterns and relationships, and forming generalizations and abstractions (Dienes, 1964). With the investigation of the objects, comparison and analysis of the similarity systemic or non-similarity (pattern) will enhance the students' reasoning ability (Christou \& Papageorgiou, 2006). Therefore, this phase is very help familiarize students use patterns and relationships to analyze mathematical situations.

Seeing the advantages of learning with abductive-deductive strategy than expository learning in facilitating the development of students'mathematical reasoning ability as described above reinforce that learning with abductive-deductive strategy better than expository learning in the achievement and improvement of students' reasoning abilities.

\section{CONCLUSION}

Based on the finding of research and discussion, it was stated conclusion that the achievements of mathematical reasoning ability students acquire learning with abductivedeductive strategy better than acquire expository learning an overall. Seen more detail by category KAM, only in the middle category that showed an achievementsof mathematical reasoning abilities students better. While the upper and under categories, both of learning show the achievement of mathematical reasoning ability students is same.

Recommended for teachers used learning with abductive-deductive strategy in materials with abductive-deductive characteristics to improve mathematical reasoning ability. Further research needs to be done for the development of learning with abductive-deductive strategy on other materials in accordance with the characteristics of abductive-deductive such linear program, logarithmic, and trigonometric. There should also be extended to the level of its application such as vocational schools and junior high schools. Extended of study and research for the improvement of the other mathematical ability to use learning with abductivedeductive strategy can also be done. For comparison also necessary to do research on the comparison with the strategy of inductive, deductive, inductive-deductive or other extension.

\section{REFERENCES}

Aliseda, A. (2007). Abductive reasoning: Challenges ahead. THEORIA. Revista de Teoría, Historia y Fundamentos de la Ciencia, 22(3), 261-270. 
Baig, S., \& Halai, A. (2006). Learning Mathematical Rules with Reasoning. Eurasia Journal of Mathematics, Science \& Technology Education, 2(2).

Bragg, L. A., Loong, E. Y. K., Widjaja, W., Vale, C., \& Herbert, S. (2015). Promoting reasoning through the Magic V task. Australian Primary Mathematics Classroom, 20(2), 10 .

Christou, C., \& Papageorgiou, E. (2007). A framework of mathematics inductive reasoning. Learning and Instruction, 17(1), 55-66.

Davis, T. M., \& Murrell, P. H. (1994). Turning Teaching into Learning. The Role of Student Responsibility in the Collegiate Experience. ERIC Digest.

Dienes, Z. P. (1964). Mathematics in the primary school: Macmillan.

Glassmeyer, D., \& Edwards, B. (2016). How Middle Grade Teachers Think about Algebraic Reasoning. Mathematics Teacher Education and Development, 18(2), 92-106.

Jones, G. A., \& Thornton, C. A. (1993). Vygotsky Revisited: Nurturing Young Children's Understanding of Number. Focus on Learning Problems in Mathematics, 15, 18-28.

Lowrie, T., Logan, T., \& Ramful, A. (2016). Spatial Reasoning Influences Students' Performance on Mathematics Tasks. Mathematics Education Research Group of Australasia.

National Council of Teachers of Mathematics (NCTM). (2000). Principles and standards for school mathematics (Vol. 1): National Council of Teachers of Mathematics.

Mullis, I. V., Martin, M. O., Ruddock, G. J., O'Sullivan, C. Y., \& Preuschoff, C. (2009). TIMSS 2011 Assessment Frameworks: ERIC.

Nataliasari, I. (2014). Penggunaan Model Pembelajaran Kooperatif Tipe Think Pair Share (TPS) untuk Meningkatkan Kemampuan Penalaran dan Pemecahan Masalah Matematis Siswa MTs. Jurnal Pendidikan dan Keguruan, 1(1).

Nizar, A. (2007). Kontribusi Matematika dalam Membangun Daya Nalar dan Komunikasi Siswa. Jurnal Pendidikan Inovatif, 2(2), 74-80.

Noto, M. S. (2015). Efektivitas Pendekatan Metakognisi terhadap Penalaran Matematis pada Matakuliah Geometri Transformasi. Infinity Journal, 4(1), 22-31.

Ormrod, J. E. (2008). Psikologi pendidikan. Jakarta: Erlangga.

Rohana, R. (2015). Peningkatan Kemampuan Penalaran Matematis Mahasiswa Calon Guru melalui Pembelajaran Reflektif. Infinity Journal, 4(1), 105-119.

Shodikin, A. (2013). Abductive-Deductive Strategy: How To Apply It In Improving Student Mathematics Literacy In Junior High School. Paper presented at the International Seminar on Mathematics, Science, and Computer Science Education, Bandung.

Shodikin, A. (2016). Peningkatan Kemampuan Pemecahan Masalah Siswa Melalui Strategi Abduktif-Deduktif Pada Pembelajaran Matematika. Kreano, Jurnal Matematika Kreatif-Inovatif, 6(2), 101-110. doi:http://dx.doi.org/10.15294/kreano.v6i2.3713.

Sumarmo, U. (2013). Kumpulan makalah berpikir dan disposisi matematik serta pembelajarannya. Jurusan Pendidikan Matematika: FMIPA UPI.

Sun, Z., Finnie, G., \& Weber, K. (2005). Abductive case-based reasoning. International Journal of Intelligent Systems, 20(9), 957-983. 
120 Shodikin, Effect of Learning with Abductive-Deductive Strategy ...

Taylor, L., \& Parsons, J. (2011). Improving student engagement. Current issues in education, 14(1). 